IJ§ER

ISSN: 2149-5939
International Journal of Social Sciences and Education Research

Online, http://dergipark.gov.tr/ijsser

Volume: 4(3), 2018

\title{
The flipped classroom approach in teaching writing: An action research
}

\author{
Gülper Güvenç ${ }^{1}$
}

Submission date: 24 / 05 / 2018

Accepted date: $01 / 07 / 2018$

\begin{abstract}
The aim of this study is to explore students' perceptions on flipped classroom (FC) approach, in which the role of school work and out-of-class content are reversed, in writing lessons in contrast to conventional teaching in accordance with an Action Research project. To achieve this, a 13-week plan was designed to provide students with multimedia tools in writing lessons. Data were collected from students' regular self-reflections, teacher's observational field notes and a final student survey. Overall, the majority of the students reflected positive feelings towards the method. On the other hand, the final survey results showed that they rated this experience neutral mostly.
\end{abstract}

Keywords: Flipped classroom, blended learning and teaching, student-centred learning, action research, technology-enhanced learning

\section{Introduction}

In the modern world of teaching and education, the transition from the traditional pedagogical methods to more innovative and technological methods is inevitable. It is possible to assume that soon we will not define "illiterate" as not being able to read and write, but not knowing how to use a computer.

The focus on "Blended Learning", which encourages student-centred, self-motivated search of knowledge, has been highlighted by the integration of communication and information technologies into educational process. The fundamental piece of blended learning is the model called "Flipped (or Inverted) Classroom", which was developed by American educators Jonathan Bergmann and Aaron Sams in 2000 (Bergman \& Sams, 2012). The authors refer their approach as "a framework that ensures students receive a personalized education tailored to their individual needs" (Bergman \& Sams, 2012, p.6).

Flipped classroom, a novel pedagogical model that focuses on learner-based instruction, has come into prominence among many researchers and practitioners all over the world. This flipped classroom approach not only helps students learn course content out of the class, but also allocates class time for interactive activities, by inverting the conventional teaching mode and engaging learners in hands on practices via group work. Hence, it ensures clearing misconceptions with the teacher and classmates via in-class discussion. This method is a model for other colleagues and/or schools to expose learners to alternative teaching techniques which may help them "think outside the box". For me, the lure of flipped classroom could be "thinking beyond the textbook." With lectures freed up from theoretical knowledge, class time can be allocated to create more open-

${ }^{1}$ TOBB University of Economics and Technology, Ankara, Turkey, gguvenc@etu.edu.tr 
Güvenç, G. (2018). The flipped classroom approach in teaching writing: An action research. International Journal of Social Sciences and Education Research, 4(3), 421- 432.

ended questions, pair or group projects, collaborative activities which can actively engage students and bring real-life integration to their studies (Bergman \& Sams, 2012; Tucker, 2012; Fulton, 2012).

In an Action Research (AR), educators work collaboratively with learners to gain increasingly deeper understanding of their learning and overcome the challenges of this practice. Action researchers follow the path through planning (being more conscious of the existing problem and acting deliberately about the inquiry), action (systematic and rigorous efforts for the intervention of the issue), observation (collecting data comprehensively about the action), reflection (developing deeper understanding and self-consciously criticizing what exists through the awareness of the situation) (Burns, 2010; Mackay, Birello \& Xerri, 2018). The last but not the least, it is of utmost importance to look back at the research after it is completed. As Radford (2007) points out:

Practitioner researchers need to be analysts and critical interpreters of practice in a way that helps them to understand and explain what is happening, but the approach is more likely to be historical, exploratory, interactive and reflectively analytical rather than directly interventionist or controlling (276).

The aim of this paper is to evaluate the perceptions and attitudes of the students towards a partially-flipped classroom approach by creating awareness in accordance with an Action Research project in an English preparatory class at TOBB University of Economics and Technology in Ankara, Turkey.

\section{Literature}

Bishop and Verleger (2013) describe flipped classroom as an educational technique which is made up of two essential components: one of them is interactive learning activities (in the classroom) and the other is web-based individual instruction (outside the classroom). According to Bransford, Brown and Cocking (2000), students spend only 14 percent of their time at school (33\% sleep, $53 \%$ home and community). Therefore, it is essential for schools to develop ways to connect classroom learning to other aspects of students' lives (Bransford, Brown, Cocking, 2000).

Before examining how to implement FC pedagogy, the comparative illustration of the traditional classroom and the FC could be presented in the following Figure 1:

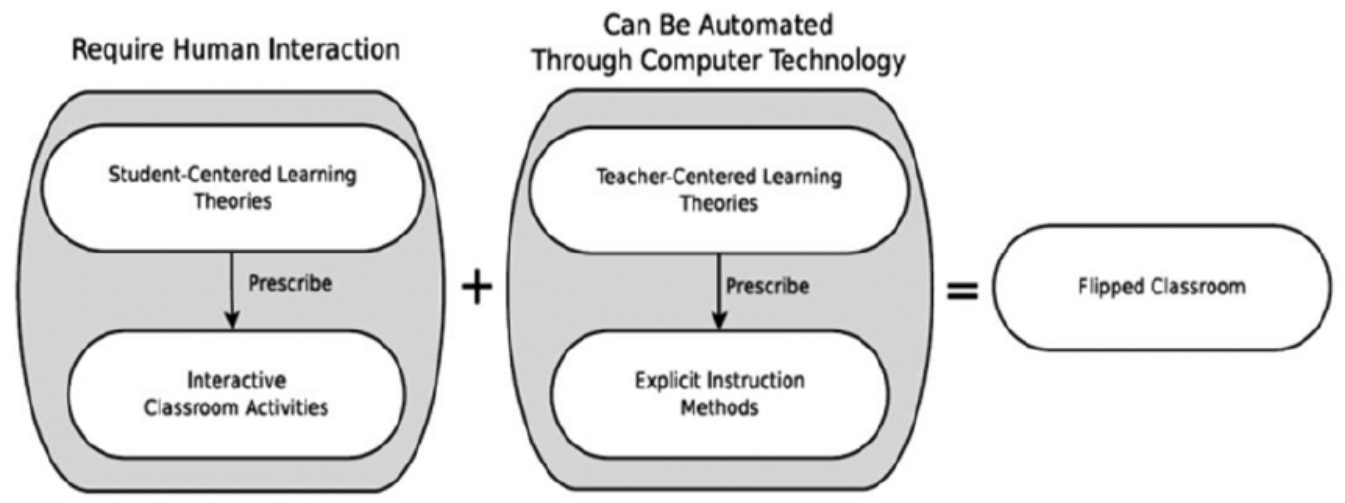

Figure 1. Flipped classroom activities (adopted from Bishop \& Verleger, 2013) 
Güvenç, G. (2018). The flipped classroom approach in teaching writing: An action research. International

Journal of Social Sciences and Education Research, 4(3), 421- 432.

Many researches have been conducted on the application and efficacy of the flipped classroom pedagogy (Szparagowski, 2014; Soliman, 2016). Evseeva and Solozhenko (2015) performed a study on the efficacy of flipped classroom methodology in the process of teaching and learning English. The results demonstrated that $85 \%$ of the students taking part in the survey favored the idea of flipped classroom in the learning process, while $15 \%$ of respondents were not interested in it due to the problems they encountered with electronic devices.

Due to its allowance for studying at personal pace and using time more effectively, this technology served as an instrument to enhance students' motivation and facilitate their autonomy. Similarly, in his study, Han (2015) flipped an intensive ESL course by exposing to digital platform for meaning- and language-focused input and providing cooperative activities for in-class sessions. The findings revealed significant development of learner autonomy.

There are also some studies regarding the impact on student achievement (Stone, 2012; Hung, 2015; Yang, Yin \& Wang, 2018). According to a research conducted by O'Flaherty and Philips (2015) on this issue, flipped mode of learning improved students' academic performance, increased teacher satisfaction and contributed to the development of lifelong learning and $21^{\text {st }}$ century skills.

Studies focusing on student perceptions (Zainuddin \& Attaran, 2016; Owston, 2013) were found to be mostly positive with the minority of some negative impression (Bell, 2015). For instance, Strayer (2012) conducted a comparative research between flipped and traditional classroom in a statistics course. According to the results of the study, students participating the flipped class were not as content as with the new teaching design compared to the non-flipped one. However, they reacted more positively towards this more innovative and collaborative education.

There are a number of advantages that make flipped classroom appealing and efficient. They can be listed as below:

- Using classroom time more effectively and creatively,

- Students' transforming from passive listeners to active learners in the learning process,

- Providing inspiration and motivation for students to prepare for class,

- Giving teachers better insight into student difficulties and learning styles,

- Increased levels of student engagement, achievement and interest,

- Use of technology to enhance the experience,

- Technology's flexibility and appropriateness for $21^{\text {st }}$ century learning,

- Students' taking their responsibility to learn on their own and becoming independent in their learning (Bergmann \& Sams, 2012; “CADQ Guide: The flipped classroom”, 2013; Herreid \& Schiller, 2013; M.K. Kim, S. M. Kim, Khera \& Getman, 2014; Lage, Platt, \& Treglia, 2000).

However, it is also important to note the possible challenges with the approach:

- Greater preparation and organization time and effort (both in-class and outside-of-class material),

- Student resistance to novel teaching methods,

- Students' coming unprepared to the class as it requires doing extra study outside the class,

- Difficulty of finding quality videos (Nederveld \& Berge, 2015; Bergmann \& Sams, 2012; Herreid \& Schiller, 2013). 
Güvenç, G. (2018). The flipped classroom approach in teaching writing: An action research. International Journal of Social Sciences and Education Research, 4(3), 421- 432.

Flipped classroom design is based on the theory of Bloom's revised taxonomy of cognitive domain. This taxonomy provides six major categories of cognitive processes, starting from the bottom to the highest level:

(1) Remembering: in this step, students recall or retrieve the information or content they have previously learned.

(2) Understanding: students comprehend the meaning, interpret the information and summarize the task.

(3) Applying: students create a process about their background knowledge or apply their understanding to real-life situations.

(4) Analysing: by using their critical thinking, students question what happened, analyse the material or concept into parts, compare the knowledge and debate with friends.

(5) Evaluating: students make judgements and assessments about the value of ideas and the whole learning process, interpret and justify.

(6) Creating: students are able to produce a new form, design by generating novel structures (Anderson et al, 2000).

In flipped classrooms, the highest level (creating) is practiced following the lower levels. In implementing flipped model, the lower forms of cognitive domains which are remembering, and understanding are presented outside the classroom through videos, readings and other materials Thus, applying, analyzing evaluating and creating as the higher levels of cognitive work can be practiced in the classroom (Krathwohl \& Anderson, 2010). Bergman (2016) stated on his blog that flipped classroom focuses on the time spent with the guidance of the facilitator on the top layers of the triangle. The following Figure 2 demonstrates the level of students' learning in the flipped model according to Bloom's revised taxonomy.

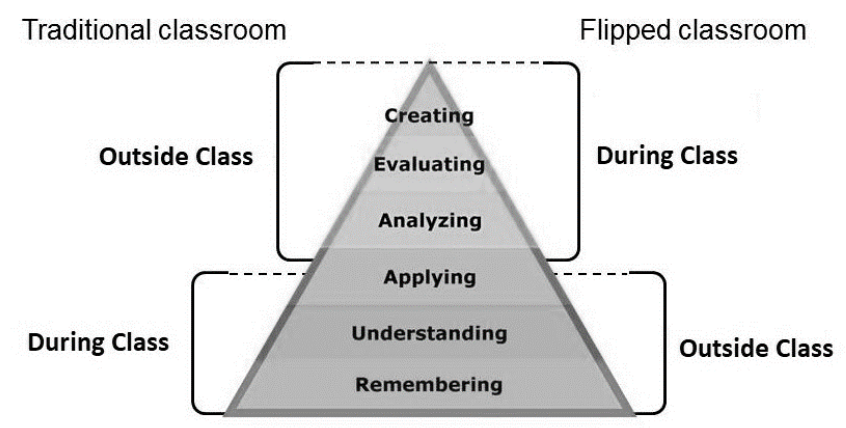

Figure 2. Bloom's revised taxonomy in the flipped classroom

\section{Methodology}

\subsection{Design, participants and setting}

Action Research is considered to be one of the activities for professional development of teachers. An AR project includes the following steps: (1) identifying a research question and relevant studies, (2) formulating a research plan, (3) systematically collecting data, (4) analyzing the data, (5) evaluating, summarizing and reporting the data, (6) sharing the study with others (Richards \& Farrel, 2005; Arksey \& O'Malley, 2005). This project aims to have an understanding of students' 
Güvenç, G. (2018). The flipped classroom approach in teaching writing: An action research. International

Journal of Social Sciences and Education Research, 4(3), 421- 432.

perspectives towards flipped classroom method and to compare their reactions towards flipped vs. conventional teaching methods by creating awareness.

It was conducted in an English Language Preparatory School on a program that aims to provide students with an intensive English course. Data were collected from a C-level (CEFR: B2-C1) Reading \& Writing class. Students were supposed to come to the lesson having studied the assigned links on flipped weeks. The participants were 23 students, evenly split by gender (13 females, 10 males) whose ages ranged from 18 to 20 . They were motivated students who gained a relatively high score in the preliminary test.

This AR project lasted throughout the term (13 weeks is total) in writing lessons, which include 4 writing practices as specified by the curriculum office for this level. As Week 5 and 9 were the Midterm weeks, there were not any writing practices in the weekly program. Students completed a short self-reflection form which asks the things they liked/disliked about the relevant week's writing lesson at the end of each writing lesson. The last three weeks of the term were allocated to data analysis and reporting. The participants received certificates prepared by the teacher upon completing the final survey.

\subsection{Description of the flipped and traditional instruction}

In accordance with the AR plan, the flipped classroom study was conducted as follows: As the first step, a class group was created on Remind (https://www.remind.com/), a mobile and online sharing platform for teachers, students and schools at the beginning of the trimester. Remind allows teachers to create groups for students and share announcements, links, attachments, photos etc. The students were already familiar with Remind; thus, no further training was necessary on its use.

Among the four writing approaches, two of them were applied with the flipped classroom method (Week $4 \& 7$ ) and the other two were studied with the traditional methods (Week $6 \&$ $10)$.

At the beginning of the term, two weeks were allocated to literature review to find out more about the theoretical background to build the research on it and to specify the focus by creating RQs to conduct the study. On Week 3, to get prepared for the next sessions/to make the study more meaningful and efficient, students were given brief information about how "Flipped Classroom" method will be applied throughout the term. Thanks to this, raising awareness (of the students) about flipped vs. conventional teaching methods was aimed.

For the content delivery, planning and preparing materials for in-class and out-of-class activities began with the Writing Approach: Advantages \& Disadvantages on the same week. For the first writing approach a WebQuest was created. Making use of the Internet as an information tool, the WebQuest model includes the following attributes:

(1) Introduction: form a basis and provides some warm-up for the topic,

(2) Task: describes the end product of the activity and leads the learners about how to organize the information,

(3) Process: describes the procedure the learners should follow in accomplishing the task by providing a set of web-based information sources,

(4) Evaluation: presents the assessment criteria, 
Güvenç, G. (2018). The flipped classroom approach in teaching writing: An action research. International Journal of Social Sciences and Education Research, 4(3), 421- 432.

(5) Conclusion: brings to an end to the quest and has the learners recall what they have achieved (Chuo, 2007; Starr, 2000).

In addition to a set of explanations, a YouTube video link was added on the process stage on the WebQuest to properly serve the purposes of the FC as well. Then, relevant links were sent to the students via Remind for the next week.

Face-to-face class time of the first flipped writing approach began with implementing a kinesthetic group activity in the lesson to be able to practice the Writing Approach: Advantages \& Disadvantages on Week 4. First, the students were divided into two groups. the teacher stuck unscrambled pieces of sentences from a sample essay he/she wrote on the wall opposite the board for each group separately and then the activity began. Standing in line in front of the wall, each student read and chose a sentence from the wall, stuck it in the correct order on the board moving as fast as possible. While they were trying the complete the essay in a rush competitively, it was observed that some group members were trying to help each other by correcting their mistakes referring to the online material, which I found rewarding. In the second lesson, they created an outline for their own essay and started writing with an introduction.

The second flipped classroom practice was conducted on Week 7 with the Writing Approach: Cause \& Effect. Prior to this practice, materials for in-class and out-of-class activities for this approach were planned and prepared. As it was observed that some of the students did not pay attention to the video that was inserted on the WebQuest within the written input, for this second FC practice only video links were planned to be prepared and searched. For this purpose, an animated video on PowToon was created. PowToon is a drag-and-drop video presentation software that allows users to create eye-catching and entertaining videos with a professional look (https://www.powtoon.com). Besides, two more educational videos on YouTube were selected on the target approach. Last, relevant links were sent to the students via Remind for the next week.

In-class activities for the second FC writing approach began with a concept map in the form a tree. In groups of 3-4, students were given a prompt on the target writing approach with tree leaves and trunk cut from cardboard and some post-its in the shape of a flower. Their task was to create a tree with the given pieces first, then brainstorm and write as many causes and effects as possible on flower-shaped post-its and stick them on separate opposing leaves of the tree in their groups within the time limit. After this activity, their understanding of transitions and connectors for cause and effect writing approach was assessed on an online tool called "Plickers" (https://www.plickers.com). Plickers is an online assessment tool made by the teacher to check student understanding with the opportunity to participate and engage students through online games and learning. The teacher projects pre-written questions and answer choices on the board. Without the need to have students use devices or pencil, students just rotate the given set of Plickers cards with the codes to show their answer. They worked cooperatively in groups of three to four to answer the questions they were assigned throughout the activity. For the last in-class practice, each student was given a copy of a graphic organizer suitable for the target approach and suggested topics to build their essay on. Having chosen their topic, they completed the organizers individually and the teacher monitored their study. Due to the limited class time and relatively large class size, there was not much time to be allocated to writing the full essay in any week.

The instruction in the traditional methods was built around in-class lectures. On Week 6, the Writing Approach: Compare \& Contrast was covered via conventional teaching methods, which 
Güvenç, G. (2018). The flipped classroom approach in teaching writing: An action research. International Journal of Social Sciences and Education Research, 4(3), 421- 432.

is while the teacher lectures, the students sit and listen. Then, the students completed the exercises in the booklet during the class hour. They were given the topics to write their essays later on. Similarly, the last writing approach: refutation was studied on the writing booklet and the exercises were completed. Writing the complete essay was assigned to the students as directed by the curriculum office.

\subsection{Data collection and analysis procedure}

For the present study, both qualitative analysis and quantitative survey methods were combined in order to provide rich description of the classroom under investigation. This mixed research design provided the researcher to get valid and reliable data from different perspectives.

Qualitative data were collected using students' regular self-reflections (open ended questions) and teacher's observational field notes as the main data source because authentic reflection would be of crucial importance in establishing credible findings. The research methodology caused me to be both an insider (course instructor) and an outsider (educational researcher).

Upon completion of all writing content, a 10-question end-of-experiment survey was assigned to students to assess perceptions and attitudes towards the new method of instruction they received. A 5-point Likert scale was used where a score of 1 was Totally Agree, 3 was Neutral and 5 was Totally Disagree.

\section{Result and discussion}

\subsection{Qualitative findings}

To gain a profound understanding of the students' perceptions and attitudes on the flipped learning in comparison to traditional education for writing lessons, students' regular self-reflections and teacher's observational field notes were analyzed. Three major categories were comprised from the analysis of the data: students' perceptions of the flipped classroom model, efficacy of the model in learning and changes in the classroom environment.

The major theme arising from the feedback was about students' positive perceptions of their experience in the flipped classroom method. A high majority of the students reported to be satisfied with the method of instruction they received. The major factor that led to satisfaction was their enjoyment of the flipped class model. They stated that it was more enjoyable and interesting compared to traditional writing lessons. In relation to students' perceptions, the following comments came from the students (Students' statements were kept the same in sentences written in italics):

Activities and examples are very catchy. Everything was great.

Actually, I like writing essay. And I liked flipped learning. We can played game.

We did activity. It was enjoyable and that technological game was very good.

I like watching video before lesson. Class activity is very cute.

Trees and flowers, our game with cards are very memorable.

Students' comments also focused on the efficacy of the model in learning. They mentioned that following the online content prior to the lesson helped them. Here are relevant comments of the students:

I think flip class is more efficient because we see two times.

I prepared for lesson so lesson is more effective for me. 
Güvenç, G. (2018). The flipped classroom approach in teaching writing: An action research. International Journal of Social Sciences and Education Research, 4(3), 421- 432.

The link you sent helped me comprehend the topic and write the essay homework.

With the flipped learning, classroom activity is spent on higher-level learning tasks such as group discussion rather than completing lower level thinking tasks such as listening to lectures and comprehension (Nederveld \& Berge, 2015).

The third theme emerging from the data was the classroom environment. It was observed that they appreciated the interactive and collaborative learning environment with media technology. As the students come to lessons preparedly and properly equipped, it makes the interaction more effective, practical and fruitful instead of taking notes monotonously about the theoretical material throughout the class time. Here are a couple of the students' comments illustrating this point:

I liked the information competition with codes. It was different.

I think making activity in the class is very good.

As indicated by Zainuddin and Attaran (2015), facilitative role of the flipped classroom approach in media technology was appreciated in teaching and learning practices. As the teachers use multimedia tools in their teaching practices, students take advantage of these technological tools in learning activities correspondingly. Roach (2014) reported in his research that students reflected in a positive way to flipped classroom because it enabled them to work collaboratively with each other and exchange ideas in problem solving.

In addition to these points, a few students expressed their dissatisfaction with the model. They mentioned the difficulties of self-studying. Here are some examples:

It's really hard to understand lesson at home lonely. We spent so much time to do this.

On the internet, I didn't understand some things. But my teacher tells me.

Apart from statements about the flipped classroom, their comments about the conventional learning focused mainly on the monotony of the lesson. They stated the following about the traditional learning environment:

We wrote a part of essay with our partners. That's good but flipped learning is more interesting and unusual. Different learning types are more interesting and enjoyable than booklet.

I don't like anything because it's very usual and traditional. Just booklet isn't enough I think. It was good but maybe more interesting could be. Some sections are boring.

According to the teacher's observational filed notes, it was noticed on Week $4^{\text {th }}$ that the students enjoyed the activity and it encouraged group work a lot. Most of the students came preparedly, but it was clear that some of them did not study the material in detail since they did not pay attention to the homework instruction in the out-of-class content. On the other hand, although some others saw the homework, they did not do it either. It could be because the instructions were not given in class personally by the teacher, it was a disincentive.

However, in the second practice on Week 7 th they understood the rationale behind flipped classroom more. According to the observational notes, it was seen that the activities went well, and the students had fun while working in small groups similar to the previous experience. Besides, one of the students stated that she benefitted from the graphic organizer which was provided as an in-class material.

Apart from these, the content on Week $6^{\mathrm{m}}$ and $10^{\mathrm{i}}$ were covered through traditional methods in a teacher-centered way. It was observed that while covering the essays on the writing booklet, 
Güvenç, G. (2018). The flipped classroom approach in teaching writing: An action research. International Journal of Social Sciences and Education Research, 4(3), 421- 432.

some of the students were not interested at all and they occasionally looked with sleepy eyes. Everything was normal, neutral and ordinary in the classroom environment.

\subsection{Quantitative findings}

As for the quantitative data, a final survey which includes 10 questions and optional comments has been conducted $(n=21)$. Table 1 lists students' level of agreement on the key items from the survey.

Table 1. Students' perceptions of flipped classroom and traditional classroom

\begin{tabular}{|c|c|c|c|c|c|c|}
\hline Survey Items & $\begin{array}{c}\text { Total } \\
\text { items, } \\
\mathbf{n}^{\mathrm{a}} \\
\end{array}$ & $\begin{array}{l}\text { Totally } \\
\text { agree, } \\
\text { n }(\%) \\
\end{array}$ & $\begin{array}{c}\text { Agree, } \\
\text { n (\%) }\end{array}$ & $\begin{array}{c}\text { Neutral, } \\
\text { n }(\%)\end{array}$ & $\begin{array}{c}\text { Disagree, } \\
\text { n (\%) }\end{array}$ & $\begin{array}{c}\text { Totally } \\
\text { disagree, } \\
\text { n }(\%) \\
\end{array}$ \\
\hline $\begin{array}{l}\text { 1. I liked reading notes on the } \\
\text { webpage design and watching vid- } \\
\text { eos rather than having straight lec- } \\
\text { ture about the topic. }\end{array}$ & 21 & $3(14)$ & $9(43)$ & $7(33)$ & $0(0)$ & $2(10)$ \\
\hline $\begin{array}{l}\text { 2. I would have liked to study via } \\
\text { traditional teaching methods in all } \\
\text { lessons. }\end{array}$ & 21 & $2(9)$ & $4(19)$ & $10(48)$ & $4(19)$ & $1(5)$ \\
\hline $\begin{array}{l}\text { 3. I would rather have the teacher } \\
\text { lecture in class and then complete } \\
\text { the exercises in the course book dur- } \\
\text { ing the class hour. }\end{array}$ & 21 & $7(33)$ & $2(10)$ & $8(38)$ & $1(5)$ & $3(14)$ \\
\hline $\begin{array}{l}\text { 4. I liked doing more collaborative } \\
\text { and engaging group work activities } \\
\text { in lesson than doing straight exer- } \\
\text { cises. }\end{array}$ & 21 & $5(24)$ & $9(43)$ & $5(24)$ & $0(0)$ & $2(9)$ \\
\hline $\begin{array}{l}\text { 5. The use of links (videos }+ \text { web- } \\
\text { site lesson format) enabled me to } \\
\text { learn the material more effectively } \\
\text { than lecture alone. }\end{array}$ & 21 & $5(24)$ & $8(38)$ & $5(24)$ & $1(5)$ & $2(9)$ \\
\hline $\begin{array}{l}\text { 6. I felt disconnected and uncom- } \\
\text { fortable without a teacher being } \\
\text { present during the virtual online } \\
\text { class. }\end{array}$ & 21 & $2(9)$ & $5(24)$ & $8(38)$ & $2(10)$ & 4 (19) \\
\hline $\begin{array}{l}\text { 7. I managed to grasp the main } \\
\text { points of the lecture with "Flipped } \\
\text { Classroom" more than I did when } \\
\text { we used traditional methods of in- } \\
\text { struction. }\end{array}$ & 21 & $1(5)$ & $3(14)$ & $12(57)$ & $2(10)$ & $3(14)$ \\
\hline $\begin{array}{l}\text { 8. I would report this experience as } \\
\text { a significant challenge and an ob- } \\
\text { stacle to learning. }\end{array}$ & 21 & $2(9)$ & $8(38)$ & $6(29)$ & $2(10)$ & $3(14)$ \\
\hline $\begin{array}{l}\text { 9. I had difficulty in having access to } \\
\text { technology for out-of-class materi- } \\
\text { als. }\end{array}$ & 21 & $2(10)$ & $3(14)$ & $11(52)$ & $3(14)$ & $2(10)$ \\
\hline $\begin{array}{l}\text { 10. I would rate my achievement } \\
\text { from this experience as positive. }\end{array}$ & 21 & $4(19)$ & $3(14)$ & $10(49)$ & $2(9)$ & $2(9)$ \\
\hline
\end{tabular}

${ }^{\mathrm{a}}$ Overall $\mathrm{n}=21$; not all participants completed the survey

More than half of the students (57\%) preferred learning the content with the flipped class technology rather than having straight lecture about the topic. Their reactions mostly stayed neutral (48\%) for studying via traditional teaching methods in all lessons. While $43 \%$ of the students would prefer to study with the conventional methods in which the teacher lectures in class and 
Güvenç, G. (2018). The flipped classroom approach in teaching writing: An action research. International Journal of Social Sciences and Education Research, 4(3), 421- 432.

then they complete the exercises in the course book during the class hour, $38 \%$ of them stayed undecided about the issue. A majority of the students (67\%) enjoyed doing more collaborative and engaging group work activities in lesson than doing straight exercises. Almost two-thirds of the students (62\%) thought that flipped classroom format (computer-based input) enabled them to learn the material more efficiently than lecture alone. $38 \%$ of them stood irresolute about feeling disconnected and uncomfortable without a teacher being present during the virtual online class. Similarly, more than half of the students (57\%) were indecisive about whether they could grasp the main points of the lecture with "Flipped Classroom" more, compared to traditional methods of instruction. Approximately half of the students (47\%) reported that they somehow had difficulty in this flipped classroom experience while $52 \%$ of them were indecisive about the statement that this challenge stemmed from having access to technology for out-of-class materials. Almost half of the students (49\%) were not certain whether they would rate their achievement from this experience as positive.

The open-ended optional comments of the survey revealed some facts about the flipped classroom format. One student approved the efficacy of this novel pedagogical approach. Concern expressed by another student included not being able to cover out-of-class materials and watching the videos. Regarding criticisms of this teaching method, this concern has been discussed in literature in a similar way (Herreid \& Schiller, 2013).

\section{Conclusion}

Evidence from this study suggests that in an AR project conducted in a college classroom, flipping the class can result in positive student attitudes and learning outcomes towards the process. Flipped classroom is a creditable approach both for enabling the instruction outside the class and for improving students' interactional competence through student-centered active learning techniques. It can be considered as a feasible and promising model in higher education since new pedagogical and practical applications are essential with the advent of new technologies.

The present study contributes to the ever-developing discipline of language teaching through the partially-flipped classroom model with an Action Research through several implications. First, it is consistent with the tenets of social constructivism as classroom applications of the flipped model supports and encourages independent and collaborative learning. In the constructivist perspective, great emphasis is placed on student to student and student to teacher interaction. Furthermore, it supports the findings of similar studies (Turan \& Göktaş, 2018; Başal, 2015; Murray, Koziniec \& McGill, 2015; Johnson, 2013) by presenting evidence for students' favorable perceptions about the flipped model as an innovative approach in the foreign language learning process, efficacy of the model in learning and changes in the classroom environment. Despite some variation among students, general reports of the student reflections and feedback were relatively consistent. Their perceptions tended to be positive with a few exceptions who wanted to follow the traditional style. The activities used in- and out-of-class have the potential to guide the lecturers in their design of similar instructional models as they considered student engagement and learning as the priority.

It is essential to emphasize that the role of flipped classroom is not aimed to replace the role of the teacher in a virtual class yet shifts the teacher's image as facilitator or navigator in the integrated education. At the beginning, it might be challenging to overcome the students' prejudice and resistance to a new method that requires them to grasp out-of-class content deeply to 
Güvenç, G. (2018). The flipped classroom approach in teaching writing: An action research. International Journal of Social Sciences and Education Research, 4(3), 421- 432.

prepare themselves for in-class material. Therefore, flipped classroom model necessitates clearly defined instructions and well-structured guiding prompts. With a clear set of guidance and planning, it can be possible to establish connections between in-class and out-of-class activities.

Furthermore, it should be noted that as this study is an Action Research project with a relatively small number of participants, some caution must be taken when generalizing the findings. Lastly, there is not any explicit and enough evidence from the reviewed literature that indicates long term comparative observations of flipped vs. traditional classroom practice. Therefore, longer consecutive offerings of these approaches need further research.

To conclude, flipped classroom is a promising, innovative and viable technology both for enhancing students' learning experiences by reversing the design of a classroom and for instructors' development of their own awareness in the classroom, what works, what does not and why, and what alternatives are convenient in their particular teaching practices.

\section{References}

Anderson, L.W., Krathwohl, D. R., Airasian, P. R., Cruikshank, K.A., Mayer, R.E., Pintrich, P. R., Raths, J., \& Wittrock, M.C. (2000). A Taxonomy for Learning, Teaching, and Assessing: A revision of Bloom's Taxonomy of Educational Objectives. New York: Pearson, Allyn \& Bacon.

Arksey, H., \& O'Malley, L. (2005). Scoping studies: Towards a methodological framework. International Journal of Social Research Methodology 8(1), 19-32. doi: 10.1080/1364557032000119616.

Başal, A. (2015). The Implementation of a Flipped Classroom in Foreign Language Teaching, Turkish Online Journal of Distance Education 16(4), 28-37.

Bell, M. R. (2015). An Investigation of the Impact of a Flipped Classroom Instructional Approach on High School Students' Content Knowledge and Attitudes Toward the Learning Environment. All Theses and Dissertations. 4444.

Bergmann, J., \& Sams, A. (2012). Flip your Classroom: Reach Every Student in Every Class Every Day. ISTE ASCD.

Bergman, J. (2016). Reframing the Flipped Learning Discussion. Retrieved from http://www.jonbergmann.com/reframing-the-flipped-learning-discussion/

Bishop, J.L., \& Verleger. M. A. (2013). The Flipped Classroom: A Survey of the Research. American Society for Engineering Association, 120th ASEE Annual Conference \& Exposition.

Bransford, J., A. Brown, \& Cocking, R. (2000). How People Learn: Brain, Mind, Experience, and School. Washington, D.C.: National Academy Press.

Burns, A. (2010). Doing action research - what's in it for teachers and institutions? IH Journal of Education and Development, 29.

CADQ Guide: The flipped classroom. (2013). Nottingham Trent University, Centre for Academic Development and Quality. Retrived from https:/www4.ntu.ac.uk/adq/document_uploads/teaching/154084.pdf

Chuo, T-W. I. (2007). The Effects of the WebQuest Writing Instruction Program on EFL Learners' Writing Performance, Writing Apprehension, and Perception. TESL-EJ 11(3). doi: 10.1016/j.sbspro.2013.06.179.

Evseeva, A., \& Solozhenko. A. (2015). Use of Flipped Classroom Technology in Language Learning. Procedia - Social and Behavioral Sciences 206, 205-209. doi: 10.1016/j.sbspro.2015.10.006.

Fulton, K. (2012). Upside down and inside out: Flip your classroom to improve student learning. Learning \& Leading with Technology 39(8), 12-17.

Han, Y. J. (2015). Successfully Flipping the ESL Classroom for Learner Autonomy. NYS TESOL JOURNAL 2(1), 98-109.

Herreid, C. F., \& Schiler, N.A. (2013). Case Studies and the Flipped Classroom. Journal of College Science Teaching 42(5), 62-66. 
Güvenç, G. (2018). The flipped classroom approach in teaching writing: An action research. International Journal of Social Sciences and Education Research, 4(3), 421- 432.

Hung, H. T. (2015). Flipping the classroom for English language learners to foster active learning. Computer Assisted Language Learning 25(1), 81-96. doi: 10.1080/09588221.2014.967701.

Johnson, G. B. (2013). Student Perceptions of the Flipped Classroom. (master's thesis). The University of British Columbia, Okanagan.

Kim, M. K., Kim, S. M., Khera, O., \& Getman, J. (2014). The experience of three flipped classrooms in an urban university: an exploration of design principles. Internet and Higher Education 22, 37-50. doi: 10.1016/j.iheduc.2014.04.003.

Kratwohl, D. R., \& Anderson, L. W. (2010). Merlin C. Wittrock and the Revision of Bloom's Taxonomy, Educational Psychologist 45(1): 64-65. doi: 10.1080/00461520903433562.

Lage, M. J., Platt, G. J., \& Treglia, M. (2000). Inverting the Classroom: A Gateway to Creating an Inclusive Learning Environment. The Journal of Economic Education 31(1), 30-43.

Mackay, J., Birello, M., \& Xerri, D. (2018). ELT Research in Action: Bridging the Gap between Research and Classroom Practice. IATEFL: United Kingdom.

Murray, D., Koziniec, T., \& McGill, T. (2015). Student Perceptions of Flipped Learning. Proceedings of the $17^{\text {th }}$ Australian Computing Education Conference (ACE 2015), Sydney, Australia.

Nederveld, A., \& Berge, Z. L. (2015). Flipped learning in the workplace. Journal of Workplace Learning 27(2), 162-172. doi: 10.1108/JWL-06-2014-0044.

O'Flaherty, J., \& Philips, C. (2015). The Use of Flipped Classrooms in Higher Education: A Scoping Review. Internet and Higher Education 25, 85-95. doi: 10.1016/j.iheduc.2015.02.002.

Owston, R., York, D., \& Murtha, S. (2013). Student perceptions and achievement in a university blended learning strategic initiative. The Internet and Higher Education 18, 38-46. doi: 10.1016/j.iheduc.2012.12.003.

Radford, M. (2007). Action research and the challenge of complexity. Cambridge Journal of Education 37(2), 263-278. doi: 10.1080/03057640701372582.

Richards, J. C., \& Farrel, T. (2005). Professional development for language teachers. Cambridge: Cambridge University Press.

Roach, T. (2014). Student perceptions toward flipped learning: New methods to increase interaction and active learning in economics. International Review of Economics Education 17, 74-84. doi: 10.1016/j.iree.2014.08.003.

Strayer, J. (2012). How learning in an inverted classroom influences cooperation, innovation and task orientation. Learning Environments Research 15, 171-193. doi: 10.1007/s10984-012-9108-4.

Szparagowski, R. (2014). The Effectiveness of the Flipped Classroom. Honors Projects. 127. Retrieved from https://scholarworks.bgsu.edu/honorsprojects/127.

Soliman, N. A. (2016). Teaching English for Academic Purposes via the Flipped Learning Approach. Procedia - Social and Behavioral Sciences 232, 122-129. doi: 10.1016/j.sbspro.2016.10.036.

Starr, L. (2000). Creating a Webquest, It's Easier than you Think, Retrieved from http://www.educationworld.com/a tech/tech/tech011.shtml

Stone, B. B. (2012). Flip your classroom to increase active learning and student engagement. In Proceedings from 28th Annual Conference on Distance Teaching \& Learning, Madison.

Tucker, B. (2012). The Flipped Classroom: Online instruction at home frees class time for learning. Retrieved from www.educationnext.org.

Turan, Z., \& Göktaş, Y. (2018). Innovative Redesign of Teacher Education ICT Courses: How Flipped Classroom Impact Motivation? Journal of Education and Future 13, 133-144. Retrieved from http://dergipark.gov.tr/jef/issue/35229/390937

Yang, J., Yin, C. X., \& Wang, W. (2018). Flipping the classroom in teaching Chinese as a foreign language. Language Learning \& Technology, 22(1), 16-26. Retrieved from http://www.lltjournal.org/item/3027.

Zainuddin Z., \& Attaran, M. (2016). Malaysian students' perceptions of flipped classroom: a case study. Innovations in Education and Teaching International 53(6), 660-670. doi: 10.1080/14703297.2015.1102079. 